Report No. BMI-1418

UC-25 Metallurgy and Ceramics (TID-4500, 15th Ed.)

Contract No. $W-7+105-$ eng -92

\title{
DEVELOPMENT OF HIGH-STRENGTH \\ CORROSION-RESISTANT \\ ZIRCONIUM ALLOYS
}

\section{by}

John A. De Mastry

Frederic R. Shober

Ronald F. Dickerson

February 22, 1960

BATTELLE MEMORIAL INSTITUTE 505 King Avenue

Columbus 1, Ohio 


\section{DISCLAIMER}

This report was prepared as an account of work sponsored by an agency of the United States Government. Neither the United States Government nor any agency Thereof, nor any of their employees, makes any warranty, express or implied, or assumes any legal liability or responsibility for the accuracy, completeness, or usefulness of any information, apparatus, product, or process disclosed, or represents that its use would not infringe privately owned rights. Reference herein to any specific commercial product, process, or service by trade name, trademark, manufacturer, or otherwise does not necessarily constitute or imply its endorsement, recommendation, or favoring by the United States Government or any agency thereof. The views and opinions of authors expressed herein do not necessarily state or reflect those of the United States Government or any agency thereof. 


\section{DISCLAIMER}

Portions of this document may be illegible in electronic image products. Images are produced from the best available original document. 


\title{
DEVELOPMENT OF HIGH-STRENGTH CORROSION-RESISTANT ZIRCONIUM ALLOYS
}

by

John A. De Mastry, Frederick R. Shober, and Ronald F. Dickerson

\begin{abstract}
Ipproximately 100 ternan and quaternary sponge-zirconium alloys u'ere screened for structural and cladding applications in a natural-uranium-fueled heanwater-moderated pou er reactor. The alloy additions stadied included 2 to 1 w'o tin, 0.5 to 2 wo molybdenum, and 1 to $3 u^{\circ}$ o niohium. The effect of 0.1 wo iron and 0.05 w' , nichel additions to the experimental allovs was evaluated. All compositions were arc melted, rolled at 850 C from a helium-atmosphere furnace, vacuum annealed $4 \mathrm{hr}$ at $700 \mathrm{C}$, and furnace cooled. Room-and elevated-temperature hardness measurements ure used to estimate the tensile strengths of the alloys, while corrosion resistance as evaluated by $1000-h$ exposures to static $300 \mathrm{C}$ uater.
\end{abstract}

On the hasis of a minimum hardness of 250 DPH and a maximum ueight gain of $30 \mathrm{mg}$ per $\mathrm{dm}^{2}$ in corrosion testing, seven zirconium alloys appeared promising for intensive evaluation for the intended application: $2 \%$ tin-0.5 w/o

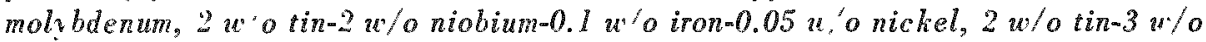
niobium 0.1 w o iron-0.05 $w$ nickel, $3 w$ o tin-0.1 w'o iron-0.05 wo nickel, $3 w / 0$ tin-0.5 w'o molybdenum-0.I w o iron- 0.05 w'o nickel, 3 w'o tin-0.5 w/o

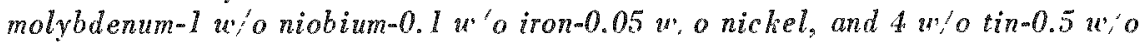
molvbrenum.

\section{INTRODUCTION}

In a natural-uranium-fueled heavy-water-moderated reactor, the volume of the reactor core and, therefore, the volume of any parasitic materials are important considerations. If such a reactor is fueled with metallic uranium, the uranium must be clad with a corrosion-resistant material as protection against the corrosive effect of the water. Cladding is also required to maintain retention of the fission products within the fuel element itself. In addition, if such a reactor is designed in such a way that the fuel and the coolant are contained within individual pressure tubes, these tubes must be resistant to corrosion by the coolant and must also have sufficient strength to withstand the pressure required to keep the coolant from boiling.

The material used for these applications must not only meet the requirements of strength and corrosion resistance but must also have a low enough thermal-neutroncapture cross section to provide maximum neutron economy. Zixcaloy- 2 has excellent corrosion resistance in water at temperatures ranging up to $680 \mathrm{~F}$, but is only a little stronger than pure zirconium. It is possible, however, to use this alloy both as pressure-tube material and as cladding by designing thick enough sections to provide the required strength. Nevertheless, the economy of neutrons in a natural uranium reactor is of such importance that a reduction of the amount of Zircaloy- 2 structural material available for parasitic capture of neutrons could provide the margin needed for economic reactor operation. The obvious approach to such a reduction would be to use a material which is substantially stronger than Zircaloy-2 and by so doing reduce the 
section of the various structural components. Fortunately, it is possible to further improve individual properties of zirconium by alloying. This approach is particularly attractive if the temperature is well below the $680 \mathrm{~F}$ associated with the acceptance test for Zircaloy-2 in pressurized-water-reactor applications.

The fact that the coolant-water temperature of the heavy-water-moderated watercooled natural-uranium-fueled reactor designed and being constructed by the E. I. du Pont de Nemours \& Co., Inc., was $570 \mathrm{~F}$ was responsible for interest in the development of a zirconium alloy having considerably more strength than Zircaloy-2 and adequate corrosion resistance in $570 \mathrm{~F}$ water. Previous investigations had shown that small additions (less than $5 \mathrm{w} / 0$ ) of molybdenum, niobium, and tin strengthen zirconium without markedly decreasing its corrosion resistance(1) and that the possibilities for developing a "tailor-made" zirconium alloy for the specific application were good. In an attempt to choose several potential alloys a research program was performed for the purpose of surveying a number of alloys for future evaluation. This investigation and the results observed are discussed in detail in subsequent sections of this report.

\section{PREPARATION OF ALIOYS}

Nine series of alloys were prepared: ternary zirconium-base alloys containing 2. $0,3.0$, and $4.0 \mathrm{w} / 0$ tin plus 0 to $2.0 \mathrm{w} / 0$ molybdenum, ternaries containing 2.0 , 3.0 , and $4.0 \mathrm{w} / 0$ tin plus 0 to $3.0 \mathrm{w} / 0$ niobium, and quaternary alloys containing 2.0 , 3.0 , and $4.0 \mathrm{w} / 0$ tin plus 0.5 to $2.0 \mathrm{w} / 0$ molybdenum and 1.0 to $3.0 \mathrm{w} / 0$ niobium. Duplicate melts of each alloying composition were prepared. These duplicate melts differed in iron and nickel content. In one melt, $0.1 \mathrm{w} / 0$ iron and $0.05 \mathrm{w} / \mathrm{o} \mathrm{nickel} \mathrm{were}$ added while in the corresponding alloy no iron or nickel was added.

Alloys were prepared by arc melting (tungsten electrode) sponge-base zirconium and appropriate alloying additions six times. The $50-\mathrm{g}$ buttons were then cast into 1 by $3 / 4$ by $1 / 4-i n$. bars prior to fabrication. Table 1 shows analyses of melting stock used. In order to ascertain if the nominal compositions of the alloys prepared were within experimental error, spot chemical analyses were performed. Table 2 lists the results of representative analyses.

Alloys containing 2.0 and $3.0 \mathrm{w} / \mathrm{o}$ tin were hot rolled at $850 \mathrm{C}$ from a helium atmosphere to $0.070 \mathrm{Ln}$. Reductions of 15 per cent per pass were obtained with no edge cracking. Alloys containing $4.0 \mathrm{w} / 0$ tin showed slight edge cracking, and the amount of reduction was therefore reduced to 10 per cent per pass. No further cracking was observed. All alloys were annealed in evacuated Vycor tubes at $700 \mathrm{C}$ for $4 \mathrm{hr}$ and furnace cooled. After annealing, specimens for corrosion evaluation, hardness measurements, and metallography were sheared from the annealed sheet.

(1) References at end. 
TABLE 1. VENDOR'S ANALYSES OF MELTING STOCKS

\begin{tabular}{|c|c|c|c|c|}
\hline \multirow[b]{2}{*}{ Impurity } & \multicolumn{4}{|c|}{ Analyses of Indicated Base Stock, ppm } \\
\hline & $\begin{array}{l}\text { Zirconium } \\
\text { Sponge }\end{array}$ & Tin & Molybdenum & Niobium \\
\hline Aluminum & 43 & -- & -- & 50 \\
\hline Arsenic & -- & 30.3 & -- & -- \\
\hline Boron & $<0.2$ & -- & -- & -- \\
\hline Carbon & -- & -- & 2 & 40 \\
\hline Chlorine & 1400 & -- & -- & -- \\
\hline Chromium & 50 & -- & $-\infty$ & $<100$ \\
\hline Cobalt & $<5$ & $-\infty$ & $-\infty$ & -- \\
\hline Coppex & 20 & 3.0 & -- & $<100$ \\
\hline Hafnium & 62 & -- & $-\infty$ & 400 \\
\hline Hydrogen & 27 & -- & -- & 4. 7 \\
\hline Iron & 150 & 50 & $-\infty$ & $<100$ \\
\hline Lead & 5 & 20 & -- & -- \\
\hline Magnesium & 938 & -- & -- & -- \\
\hline Manganese & 15 & $-\infty$ & - & $-\infty$ \\
\hline Molybdenum & $-\infty$ & -- & Balance & 50 \\
\hline Nickel & $<10$ & -- & -- & - \\
\hline Niobium & -- & -- & -- & Balance \\
\hline Nitrogen & 34 & $-\infty$ & 2 & 29 \\
\hline Oxygen & 1000 & -- & $-\infty$ & 870 \\
\hline Silicon & 50 & $-\infty$ & -- & $<100$ \\
\hline Tantalum & -- & $-\infty$ & -- & $<1500$ \\
\hline Tin & $-\infty$ & Balance & -- & -- \\
\hline Titanium & $<30$ & - & -- & 50 \\
\hline Vanadium & $<20$ & $-\infty$ & -- & $-\infty$ \\
\hline Zirconium & Balance & 3 & $-\infty$ & 500 \\
\hline
\end{tabular}

TABLE 2. ANALYSES OF SPONGE ZIRCONIUM-BASE ALLOYS

\begin{tabular}{|c|c|c|c|c|c|}
\hline \multirow[b]{2}{*}{ Nominal Composition, w/o } & \multicolumn{5}{|c|}{ Analyzed Composition, w/o } \\
\hline & $\overline{\mathrm{Sn}}$ & $\mathrm{Mo}$ & $\mathrm{Nb}$ & $\mathrm{Fe}$ & $\mathrm{Ni}$ \\
\hline $\mathrm{Zr}-2.0 \mathrm{Sn}-0.5 \mathrm{Mo}$ & 2.1 & 0.43 & $-\infty$ & - & -- \\
\hline $\begin{array}{l}\mathrm{Zr}-3.0 \mathrm{Sn}-0.5 \mathrm{Mo}-1.0 \mathrm{Nb}-0.1 \\
\mathrm{Fe} 0.05 \mathrm{Ni}\end{array}$ & 3.1 & 0.37 & 1.3 & 0.099 & 0.057 \\
\hline $\mathrm{Zx}-4.0 \mathrm{Sn}-2.0 \mathrm{MOm}-3.0 \mathrm{Nb}$ & 4.0 & 1.4 & 3.7 & - & -- \\
\hline
\end{tabular}




\section{ALLOI HARDNESS AT ROON AND ELEVATED TEMPERATURES}

Room-temperature hardness values were used as a tool to estimate the tensile strengths of alloys being studicd. The tensile strength was estimated from the hardness-strength relationship. (2) A roon-temperature hardness parameter of 250 was selected since it would yield an estimated increase of 12,000 psi in the roomtemperature tensile strength over that of Zircaloy-2.

Room-temperature hardness values of alloys studied showed progressive in$c r e a s e s$ in hardness for total alloying additions up to $5 \mathrm{w} / \mathrm{o}$. Above $5 \mathrm{w} / \mathrm{o}$ no appreciable increases in hardness were noted up to $9 \mathrm{w} / 0$ total alloying content. Figure 1 shows graphically this increase in hardness. The greatest increases in hardnesses appear to be due to the tin additions. Compositional variations from the nominal values make it difficult to assign any significance to hardness increases or decreases of individual alloys. Room-temperature hardness numbers are shown in Table 3.

After evaluation of the room-temperature hardness values, alloys were selected which showed promise of high strength (based on hardness - strength relationship) for hot-hardness study. The hardness of a large number of alloys had been increased significantly; therefore, corrosion data were also taken into consideration in selecting alloys for hot-hardness measurements. Diamond-pyramid hardnesses of the alloys selected were obtained at elevated temperatures by means of a vacuum hot-hardness machine. In this apparatus, the specimen and stage are heated by a resistance-type furnace immediately surrounding them, and the specimen is placed directly over thermocouples fitted into the stage from below. Indentations were made by lowering the indenter until its full weight $(730 \mathrm{~g})$ rested on the specimen for $15 \mathrm{sec}$. At least five indentations were made at 200, 300, and $400 \mathrm{C}$. Four impressions were made at $600,700,800$, and $900 \mathrm{C}$.

Increasing the tin content resulted in increased hot-hardness values. The effect is shown in Figure 2. The values obtained here for the 2.0 and $4.0 \mathrm{w} / 0$ tin alloys show good agreement with previously reported data. (2) Increasing the tin content from 1.5 to $4.0 \mathrm{w} / 0$ results in an increase in hardness at $300 \mathrm{C}$ of $50 \mathrm{DPH}$. This corresponds to an estimated (3) increase in tensile strength of $15,000 \mathrm{psi}$. Increasing the tin content in alloys containing $0.5 \mathrm{w} / 0$ molybdenum also results in significant increases in hardness numbers at $300 \mathrm{C}$ (above the hardness of Zircaloy-2). The hardness is not increased at $300 \mathrm{C}$ with increases in tin content from 3.0 to $4.0 \mathrm{w} / 0$ tin. This is shown in Figure 3. In alloys containing $1.0 \mathrm{w} / 0$ molybdenum and $1 \mathrm{w} / 0$ niobium, there is an increase in hardness over that of Zircaloy-2 of $90 \mathrm{DPH}$ (105 to $195 \mathrm{DPH}$ ) at $300 \mathrm{C}$ for alloys containing 4 w/o tin. This is shown graphically in Figure 4 . It appears that in alloys containing larger amounts of total alloying additions, increases in tin content result in greater increases in hot hardness than in the more dilute alloys (Figures 3 and 4). Figure 5 shows the curves obtained for alloys containing $2.0 \mathrm{w} / 0$ molybdenum and 3.0 w/o niobium. The greater increases in hardness evident in Figure 5 are due to total alloying content. In Figure 6, where the total alloying content (excluding tin) is shown, it appears that other alloying additions and tin have an equal effect on the hot-hardness values at $300 \mathrm{C}$. Table 4 lists the hot-hardness values obtained on selected representative alloys. 


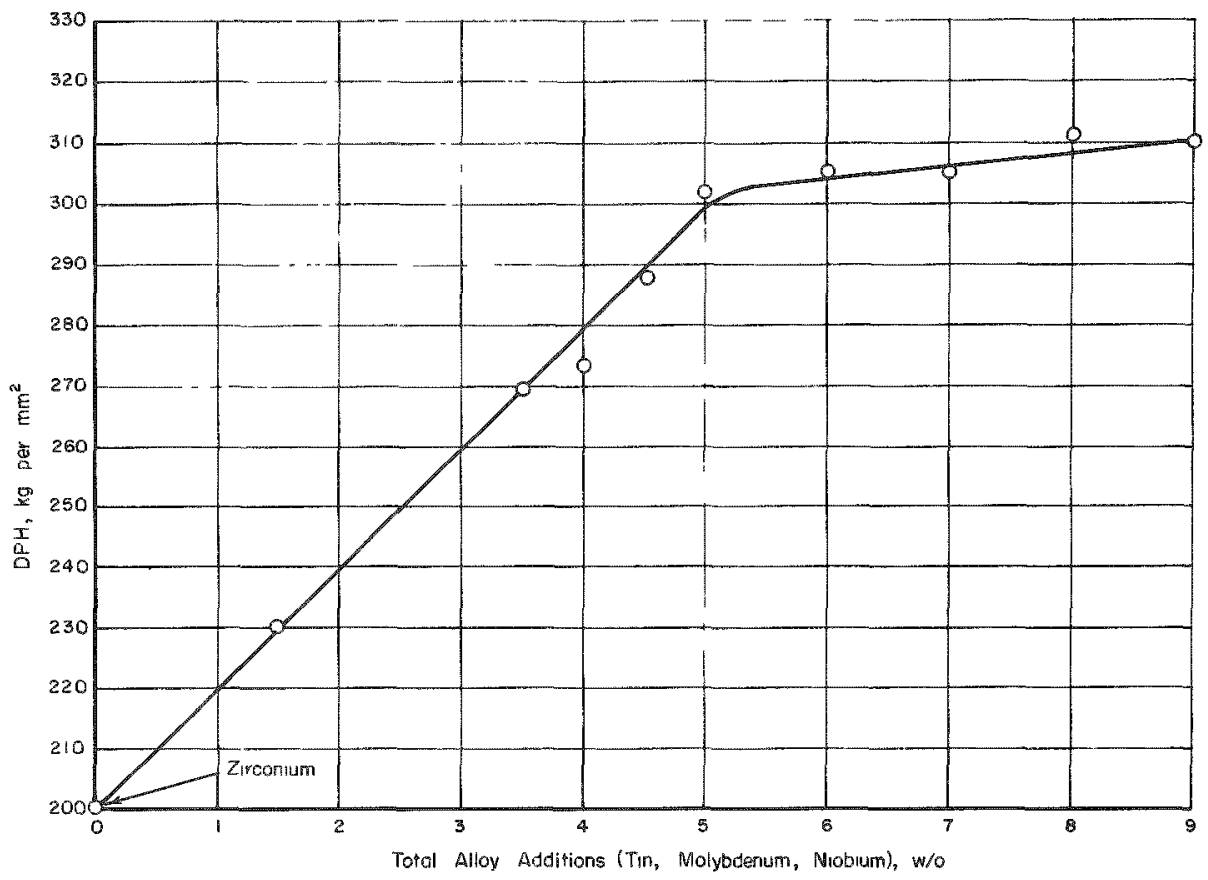

FIGURE 1. EFFECT OF IOTAL ALLOYING ADDITIONS ON ROOM-TEMPERATURE HARDNESS OF ZIRCONIUM-BA.SE STOCK

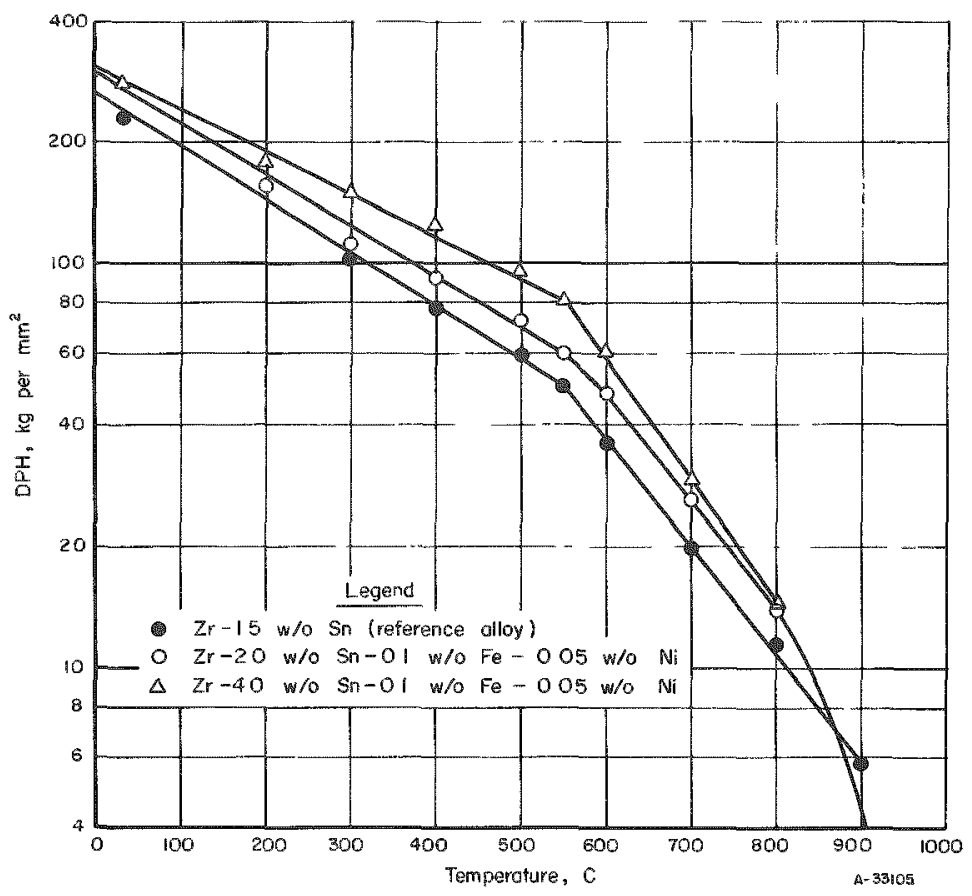

FIGURE 2. EFFECT OF INCREASING TIN CONTEN I ON THE HOT HARDNESS OF ZIRCONIUM-BASE ALLOYS 
TABLE 3. ROOM-TEMPERATURE HARDNESSES AND CORROSION BEHAVIOR IN 300 C WATER OF THE ZIRCONIUM ALLOYS PREPARED IN THE PROGRAM

\begin{tabular}{|c|c|c|c|c|c|c|c|c|}
\hline \multirow[b]{2}{*}{ Alloy } & \multicolumn{5}{|c|}{$\begin{array}{l}\text { Nominal Alloying Additions } \\
\text { (Balance Zirconium), w/o }\end{array}$} & \multirow{2}{*}{$\begin{array}{c}\text { Room-Temperature } \\
\text { Hardness, DPH }\end{array}$} & \multicolumn{2}{|c|}{$\frac{1000-\mathrm{Hr} \text { Corrosion in } 300 \mathrm{C} \text { Water }}{\text { Weight Gain(a) }}$} \\
\hline & $\mathrm{Sn}$ & Mo & $\mathrm{Nb}$ & Fe & $\overline{\mathrm{N} i}$ & & mg per $\mathrm{dm}^{2}$ & Appearance(b) \\
\hline 1 & 2.0 & -- & $-\infty$ & $\cdots$ & $-\infty$ & 262 & 12 & $G$ \\
\hline 2 & 2.0 & $-\infty$ & -- & 0.1 & 0.05 & 279 & 23 & $G$ \\
\hline 3 & 2.0 & 0.5 & -- & -- & -- & 299 & 18 & $G$ \\
\hline 4 & 2.0 & 0.5 & - & 0.1 & 0.05 & 256 & 23 & $G$ \\
\hline 5 & 2.0 & 1.0 & $=-$ & - & -- & 292 & 25 & $G$ \\
\hline 6 & 2.0 & 1.0 & -- & 0.1 & 0.05 & 274 & 25 & $\mathrm{M}$ \\
\hline 7 & 2.0 & 2.0 & -- & -- & -- & 323 & 30 & $M$ \\
\hline 8 & 2.0 & 2.0 & -- & 0.1 & 0.05 & 285 & 27 & $\mathbf{M}$ \\
\hline 9 & 2.0 & -- & 1.0 & -- & -- & 285 & 25 & $\mathrm{M}$ \\
\hline 10 & 2.0 & -- & 1.0 & 0.1 & 0.05 & 264 & 26 & $\mathrm{M}$ \\
\hline 11 & 2.0 & - & 2.0 & $\infty$ & $-\infty$ & 295 & 12 & $G$ \\
\hline 12 & 2.0 & - & 2,0 & 0.1 & 0.05 & 307 & 14 & $G$ \\
\hline 13 & 2.0 & - & 3.0 & -- & - & 361 & 29 & $\mathrm{M}$ \\
\hline 14 & 2.0 & -- & 3.0 & 0.1 & 0.05 & 297 & 14 & $\mathrm{M}$ \\
\hline 15 & 2.0 & 0.5 & 1.0 & -- & -- & 279 & 25 & $\mathbf{M}$ \\
\hline 16 & 2.0 & 0.5 & 1.0 & 0.1 & 0.05 & 260 & 23 & $M$ \\
\hline 17 & 2.0 & 0.5 & 2.0 & $-\infty$ & - & 258 & 27 & $M$ \\
\hline 18 & 2.0 & 0.5 & 2.0 & 0.1 & 0.05 & 270 & 21 & $M$ \\
\hline 19 & 2.0 & 0.5 & 3.0 & -- & -- & 274 & 19 & $M$ \\
\hline 20 & 2.0 & 0.5 & 3.0 & 0.1 & 0.05 & 240 & 18 & s \\
\hline 21 & 2.0 & 1.0 & 1.0 & -- & -- & 283 & 33 & S \\
\hline 22 & 2.0 & 1.0 & 1.0 & 0.1 & 0.05 & 264 & 28 & $s$ \\
\hline 23 & 2.0 & 1.0 & 2,0 & $-\infty$ & -- & 283 & 34 & $W$ \\
\hline 24 & 2.0 & 1.0 & 2.0 & 0.1 & 0.05 & 283 & 26 & s \\
\hline 25 & 2.0 & 1.0 & 3.0 & -- & -- & 276 & 24 & $s$ \\
\hline 26 & 2.0 & 1.0 & 3.0 & 0.1 & 0.05 & 290 & 44 & W \\
\hline 27 & 2.0 & 2.0 & 1.0 & -- & $-\infty$ & 294 & 58 & $W$ \\
\hline 28 & 2,0 & 2.0 & 1.0 & 0.1 & 0.05 & 312 & 68 & W \\
\hline 29 & 2.0 & 2.0 & 2.0 & -- & -- & 302 & 50 & $W$ \\
\hline 30 & 2.0 & 2.0 & 2.0 & 0.1 & 0.05 & 308 & 62 & W \\
\hline 31 & 2.0 & 2.0 & 3.0 & -- & -- & 302 & 68 & W \\
\hline 32 & 2.0 & 2.0 & 3.0 & 0.1 & 0.05 & 307 & 62 & W \\
\hline 33 & 3.0 & -- & - & $\ldots$ & -- & 279 & 3 & $G$ \\
\hline 34 & 3.0 & -- & - & 0.1 & 0.05 & 312 & 12 & $G$ \\
\hline 35 & 3.0 & 0.5 & $=$ & -- & -- & 283 & 12 & $G$ \\
\hline 36 & 3.0 & 0.5 & $\cdots$ & 0.1 & 0.05 & 304 & 15 & $G$ \\
\hline 37 & 3.0 & 1.0 & $\cdots$ & $-\infty$ & -- & 276 & 19 & $G$ \\
\hline 38 & 3.0 & 1.0 & - & 0.1 & 0.05 & 281 & 25 & G \\
\hline 39 & 3.0 & 2.0 & - & -- & $-\infty$ & 279 & 27 & $\mathrm{M}$ \\
\hline 40 & 3.0 & 2.0 & - & 0.1 & 0.05 & 274 & 24 & $G$ \\
\hline 41 & 3.0 & -- & 1.0 & $-\infty$ & - & 270 & 17 & $G$ \\
\hline 42 & 3.0 & -- & 1.0 & 0.1 & 0.05 & 253 & 22 & $G$ \\
\hline 43 & 3.0 & - & 2.0 & $-\infty$ & $\cdots$ & 292 & 15 & $G$ \\
\hline 44 & 3.0 & -- & 2.0 & 0.1 & 0.05 & 292 & 27 & $\mathrm{M}$ \\
\hline 45 & 3.0 & -- & 3.0 & -- & $-\infty$ & 297 & 25 & $\mathrm{M}$ \\
\hline 46 & 3.0 & -- & 3.0 & 0.1 & 0.05 & 299 & 23 & $\mathbf{M}$ \\
\hline 47 & 3.0 & 0.5 & 1.0 & -- & -- & 306 & 19 & $\mathrm{G}$ \\
\hline 48 & 3.0 & 0.5 & 1.0 & 0.1 & 0.05 & 319 & 19 & $G$ \\
\hline 49 & 3.0 & 0.5 & 2.0 & -- & $\cdots$ & 297 & 20 & $G$ \\
\hline 50 & 3.0 & 0.5 & 2.0 & 0.1 & 0.05 & 281 & 25 & $\mathrm{M}$ \\
\hline 51 & 3.0 & 0.5 & 3.0 & $\infty$ & -- & 289 & 24 & $\mathrm{M}$ \\
\hline
\end{tabular}


TABLE 3. (Contmined)

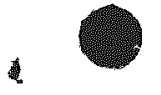

\begin{tabular}{|c|c|c|c|c|c|c|c|c|}
\hline \multirow[b]{3}{*}{ Ailoy } & \multirow{2}{*}{\multicolumn{5}{|c|}{$\begin{array}{l}\text { Nominal Alloying Audutions } \\
\text { (Balance Zirconiun), W/o }\end{array}$}} & \multirow{3}{*}{$\begin{array}{c}\text { Roon-Tempurature } \\
\text { Hardness, DPH }\end{array}$} & \multicolumn{2}{|c|}{ 1000-Hr Corrosion in $300 \mathrm{C}$ Water } \\
\hline & & & & & & & \multirow{2}{*}{$\begin{array}{l}\text { Weight Gain(a), } \\
\text { mg per dm }\end{array}$} & \multirow[b]{2}{*}{ Appearance $^{(\mathrm{b})}$} \\
\hline & $\overline{S i n}$ & $\mathrm{Mo}$ & $\mathrm{Nb}$ & $\mathrm{FC}$ & $\overline{\mathrm{Ni}}$ & & & \\
\hline 52 & 3.0 & 0.5 & 3.0 & 0.1 & 0.05 & 285 & 29 & $S$ \\
\hline 53 & 3.0 & 1.0 & 1.0 & $=-$ & $-\infty$ & 327 & 23 & $M$ \\
\hline 54 & 3.0 & 1.0 & 1.0 & 0.1 & 0.05 & 312 & 33 & s \\
\hline 55 & 3.0 & 1.0 & 2.0 & -- & -. & 309 & 34 & s \\
\hline 56 & 3.0 & 1.0 & 2.0 & 0.1 & 0.05 & 299 & 47 & $w$ \\
\hline 57 & 3.0 & 1.0 & 3.0 & $\ldots$ & - & 293 & 32 & W \\
\hline 58 & 3,0 & 1.0 & 3.0 & 0.1 & 0.05 & 294 & 34 & $s$ \\
\hline 59 & 3.0 & 2.0 & 1.0 & $\cdots$ & -- & 312 & 47 & W \\
\hline 60 & 3.0 & 2.0 & 1.0 & 0.1 & 0.05 & 317 & 40 & $\mathrm{~W}$ \\
\hline 61 & 3.0 & 2.0 & 2.0 & -. & - & 299 & 42 & $W$ \\
\hline 62 & 3.0 & 2.0 & 2.0 & 0.1 & 0.05 & 319 & 61 & $W$ \\
\hline 63 & 3.0 & 2.0 & 3.0 & $-\infty$ & $-\infty$ & 322 & 46 & $w$ \\
\hline 64 & 3.0 & 2.0 & 3.0 & 0.1 & 0.05 & 319 & 68 & $w$ \\
\hline 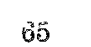 & 4.0 & $=$ & $-\infty$ & $=$ & $-\infty$ & 309 & 21 & $G$ \\
\hline 66 & 4.0 & -. & $\ldots$ & 0.1 & 0.05 & 304 & 21 & $G$ \\
\hline 67 & 4.0 & 0.5 & $=$ & -- & - & 333 & 21 & $G$ \\
\hline 68 & 4.0 & 0.5 & -- & 0.1 & 0.05 & 322 & 24 & $G$ \\
\hline 69 & 4.0 & 1.0 & $\ldots$ & -. & -- & 293 & 19 & $G$ \\
\hline 70 & 4.0 & 1.0 & $-\infty$ & 0.1 & 0.05 & 299 & 24 & $G$ \\
\hline 71 & 4.0 & 2.0 & -- & $-\infty$ & $-\infty$ & 294 & 17 & $G$ \\
\hline 72 & 4.0 & 2.0 & $\ldots$ & 0.1 & 0.05 & 304 & 28 & $M$ \\
\hline 73 & 4.0 & $-\infty$ & 1.0 & - & -- & 330 & 19 & $G$ \\
\hline 74 & 4.0 &.- & 1.0 & 0.1 & 0.05 & 287 & 21 & $G$ \\
\hline 75 & 4.0 & -. & 2.0 & -- & - & 299 & 16 & $G$ \\
\hline 76 & 4.0 & -. & 2.0 & 0.1 & 0.05 & 302 & 19 & $G$ \\
\hline 77 & 4.0 & -. & 3.0 & -- & $-\infty$ & 302 & 20 & $M$ \\
\hline 78 & 4.0 & $-\infty$ & 3.0 & 0.1 & 0.05 & 299 & 26 & $M$ \\
\hline 79 & 4.0 & 0.5 & 1.0 & -- & - & 322 & 20 & $G$ \\
\hline 30 & 4.0 & 0.5 & 1.0 & 0.1 & 0.05 & 333 & 16 & $G$ \\
\hline 81 & 4.0 & 0.5 & 2.0 & -- & $\ldots$ & 322 & 14 & $G$ \\
\hline 82 & 4.0 & 0.5 & 2.0 & 0.1 & 0.05 & 306 & 22 & $M$ \\
\hline 83 & 4.0 & 0.5 & 3.0 & $\ldots$ & -. & 333 & 20 & $\mathrm{M}$ \\
\hline 84 & 4.0 & 0.5 & 3.0 & 0.1 & 0.05 & 314 & 22 & $\mathrm{~s}$ \\
\hline 85 & 4.0 & 1.0 & 1.0 & -- & -. & 330 & 20 & $G$ \\
\hline 26 & 4.0 & 1.0 & 1.0 & 0.1 & 0.05 & 300 & 28 & $S$ \\
\hline 87 & 4.0 & 1.0 & 2.0 & $-\infty$ & - & 317 & 27 & $\mathrm{~S}$ \\
\hline 88 & 4.0 & 1.0 & 2.0 & 0.1 & 0.05 & 304 & 26 & $\mathrm{~s}$ \\
\hline 89 & 4.0 & 1.0 & 3.0 & - & -- & 322 & 26 & $S$ \\
\hline 90 & 4.0 & 1.0 & 3.0 & 0.1 & 0.05 & 289 & 26 & $\mathrm{~s}$ \\
\hline 91 & 4.0 & 2.0 & 1.0 & $\ldots$ & - & 308 & 31 & $s$ \\
\hline 92 & 4.0 & 2.0 & 1.0 & 0.1 & 0.05 & 302 & 24 & $s$ \\
\hline 93 & 4.0 & 2.0 & 2.0 & -. & - & 311 & 26 & $W$ \\
\hline 94 & 4.0 & 2.0 & 2.0 & 0.1 & 0.05 & 302 & 35 & W \\
\hline .95 & 4.0 & 2.0 & 3.0 & -- & -. & 318 & 29 & $W$ \\
\hline$y i$ & \pm .0 & 2.0 & 3.0 & 0.1 & 0.05 & 301 & 52 & $w$ \\
\hline 47 & $1 . \tilde{\jmath}$ & - & $=$ & $\ldots$ & - & 243 & 26 & $G$ \\
\hline 98 & 1.5 & -- & $=$ & 0.1 & 0.05 & 392 & 25 & $G$ \\
\hline
\end{tabular}

(a) Average of three specimens.

(b) Code:

$G=$ Black oxide $\quad M=$ Mulky

$S=$ Slightly nottled $W=$ Mottled 


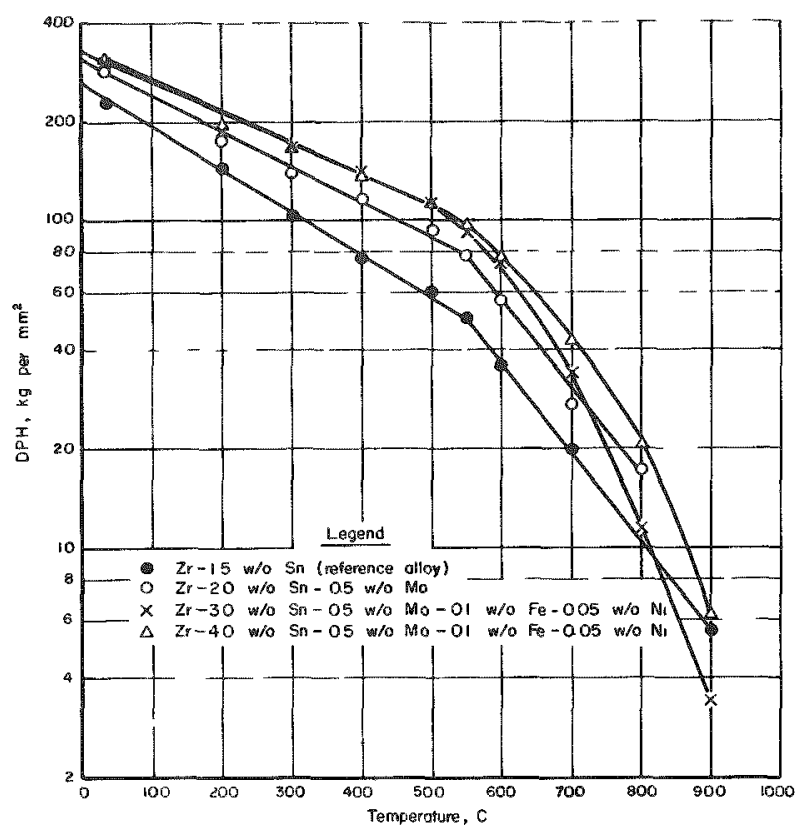

FIGURE 3. EFFECT OF INCREASING TIN CONTEN I ON HOT HARDNESS IN TERNARY ZIRCONIUM ALLOYS CONTAINING 0.5 w/O MOLYBDENUM

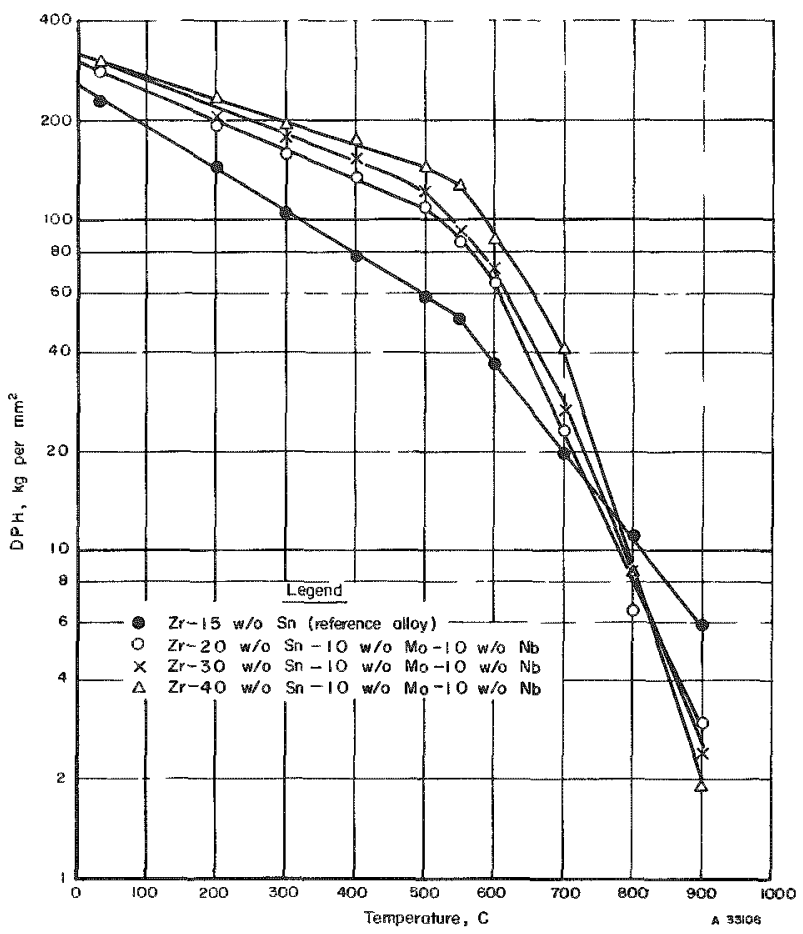

FIGURE 4. EFFECT OF INCREASING TIN CONTENT ON HOT HARDNESS IN QUATERNARY ZIRCONIUM ALLOYS CONTAINING $1.0 \mathrm{w} / 0$ MOLYBDENUM AND $1.0 \mathrm{w} / \mathrm{O}$ NIOBIUM 


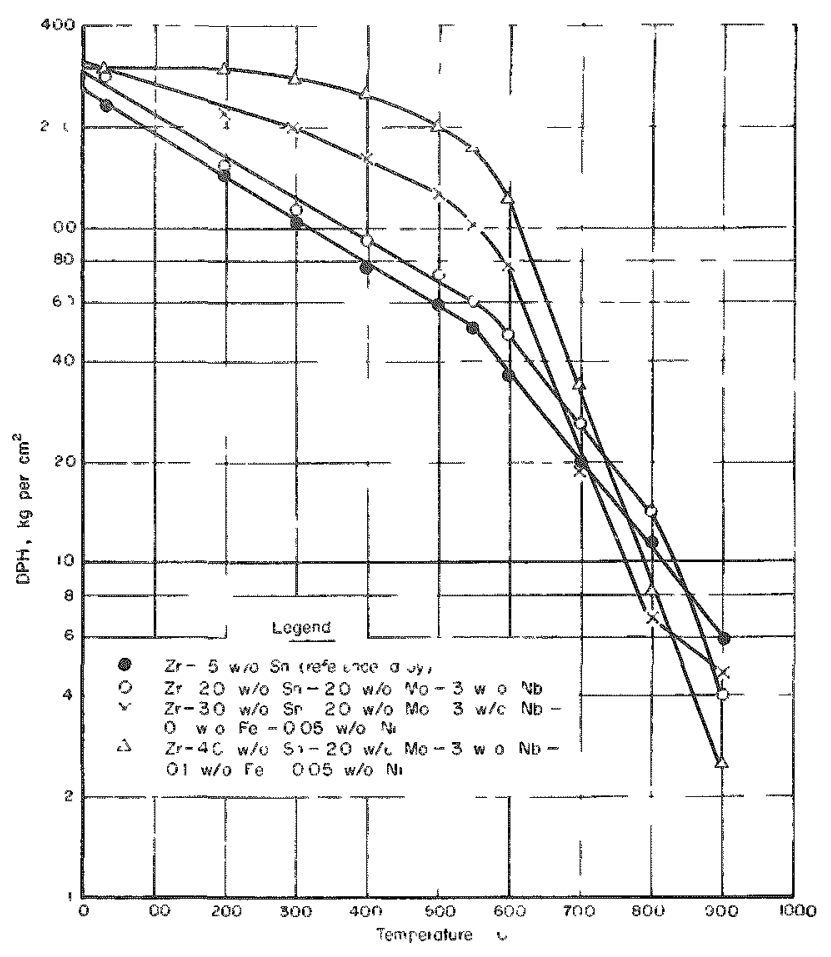

FIGURE 5. EFFEC 1 OF INCREASING TIN CONTENT ON HOT HARDNESS IN 14 U NARY ZIRCONIUM ALIOYS CON 1 AINING 2.0 $\%$ O MOLYBDENUM AND 3. W/O NIOBIUM

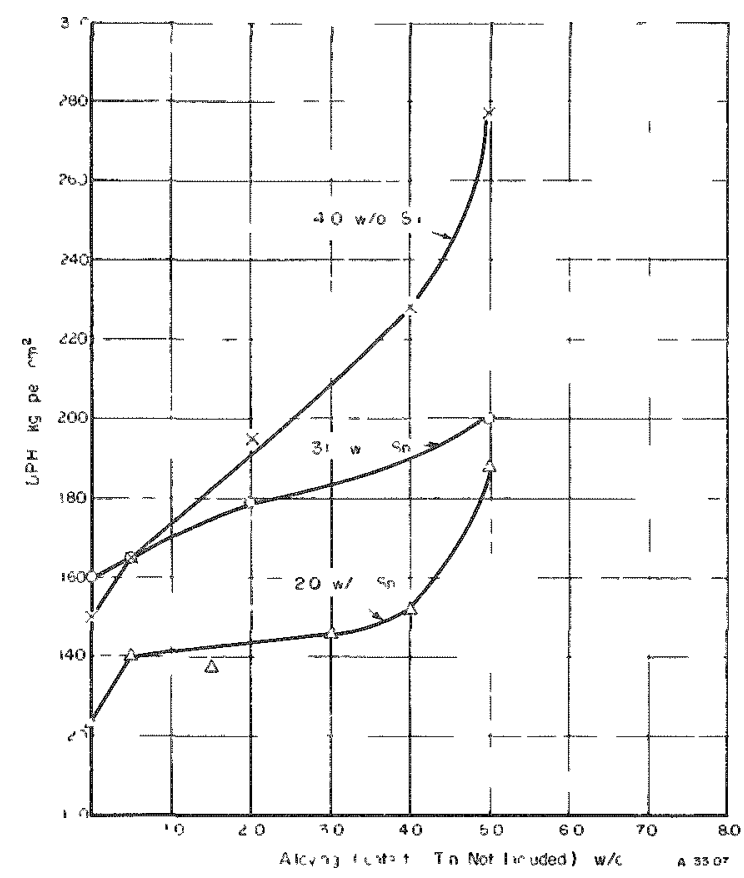

FIGURE 6. EFFECT ON ALLOYING ADDIIIONS ON HOT HARDNESS OF IIRCONIUM AI $300 \mathrm{C}$ 
TABLE 4. HARDNESS OF SPONGE-ZIRCONIUM ALLOYS AT ELEVATED TEMPERA TURES

\begin{tabular}{|c|c|c|c|c|c|c|c|c|c|c|c|c|c|c|}
\hline \multicolumn{5}{|c|}{$\begin{array}{l}\text { Nominal Alloying Adulitions } \\
\text { (Balance Zirconium), w/o }\end{array}$} & \multicolumn{10}{|c|}{ DPHN at Temperature Shown, $\mathrm{kg}$ per $\mathrm{mm}^{2}$} \\
\hline $\mathrm{Sn}$ & Mo & $\mathrm{Nb}$ & $\mathrm{Fe}$ & $\mathrm{Ni}$ & Room & $200 \mathrm{C}$ & $300 \mathrm{C}$ & $400 \mathrm{C}$ & $500 \mathrm{C}$ & $550 \mathrm{C}$ & $600 \mathrm{C}$ & $700 \mathrm{C}$ & $800 \mathrm{C}$ & $900 \mathrm{C}$ \\
\hline 2.0 & $-\infty$ & -- & 0.1 & 0.05 & 292 & 157 & 113 & 92.7 & 73.2 & 60.9 & 48.2 & 26.2 & 1.4 .2 & 4.0 \\
\hline 2.0 & 0.5 & $\cdots$ & -- & -- & 289 & 174 & 140 & 117 & 93.2 & 79.1 & 57.5 & 27.3 & 17.4 & $-\infty$ \\
\hline 2.0 & 0.5 & 1.0 & -- & -- & 264 & 168 & 137 & 120 & 95.8 & 76.4 & 54.2 & 24.6 & 8.3 & - \\
\hline 2.0 & 1.0 & 1.0 & $-\infty$ & - & 287 & 199 & 160 & $136^{\circ}$ & 110 & 86.1 & 65.7 & 23.7 & 0.6 & 3.0 \\
\hline 2.0 & 1.0 & 2.0 & -- & - & 267 & 168 & 146 & 124 & 103 & 85.2 & 58.8 & 20.7 & 0.2 & -- \\
\hline 2.0 & 1.0 & 3.0 & -- & - & 274 & 177 & 145 & 126 & 108 & 97.2 & 69.6 & 27.4 & 3.3 & $\cdots$ \\
\hline 20 & 2.0 & 3.0 & -- & - & 312 & 209 & 187 & 167 & 131 & 106 & 76.2 & 20.9 & 8.0 & 6.0 \\
\hline 3.0 & 0.5 & -- & 0.1 & 0.05 & 299 & 188 & 165 & 142 & 112 & 92.7 & 72.6 & 34.8 & 11.4 & 3.4 \\
\hline 3.0 & - & 3.0 & $=$ & -- & 263 & 182 & 159 & 138 & 111 & 91.4 & 64.6 & 24.1 & 8.1 & 1.9 \\
\hline 3.0 & 1.0 & 1.0 & - & -- & 292 & 203 & 179 & 154 & 121 & 91.7 & 70.9 & 26.9 & 8.6 & 2.4 \\
\hline 3.0 & 2.0 & 3.0 & 0.1 & 0.05 & 295 & 225 & 200 & 165 & 127 & 104 & 77.4 & 19.6 & 5.9 & 4.0 \\
\hline-1.0 & - & - & 0.1 & 0.05 & 287 & 177 & 150 & 127 & 98.6 & 81.3 & 61.4 & 29.3 & 14.7 & $\ldots$ \\
\hline$\frac{1}{2} .0$ & 0.5 & - & 0.1 & 0.05 & 304 & 196 & 165 & 135 & 111 & 96.0 & 77.1 & 42.9 & 20.6 & 6.2 \\
\hline$t_{0} 0$ & -- & 3,0 & - & -- & 270 & 193 & 163 & 137 & 118 & 105 & 72.7 & 27.8 & 10.9 & 2.1 \\
\hline 4.0 & 1.0 & 1.0 & -- & - & 299 & 233 & 195 & 178 & 148 & 128 & 88.9 & 40.3 & 8.8 & 1.9 \\
\hline 1.0 & 1.0 & 3.0 & 0.1 & 0.5 & 279 & 261 & 228 & 212 & 105 & 120 & 77.0 & 25.6 & 7.9 & 2.7 \\
\hline 1.0 & 2.0 & 3.0 & 0.1 & 0.5 & 299 & 299 & 277 & 249 & 200 & 177 & 1.22 & 34.4 & 8.3 & 2.5 \\
\hline \multicolumn{5}{|c|}{ Zircaloy-2(a) } & 232 & 145 & 104 & 77.6 & 59.3 & 50.1 & 36.6 & 19.9 & 11.4 & 5.8 \\
\hline
\end{tabular}

(a) Reference alloy made up with same sponge zirconium as alloys listed above. 
Using the hardness of Zircaloy -2 at both room temperature (220 DPH) and at $300 \mathrm{C}(104 \mathrm{DPH})$ as a reference, it can be seen that large increases in hardness have been obtained. At both room and elevated temperatures the most beneficial addition appears to be tin and tin in combination with molybdenum.

\section{ALLOY CORROSION EVALUATION}

A maximum total weight-gain corrosion parameter of $30 \mathrm{mg}$ per $\mathrm{dm}^{2}$ in $1000 \mathrm{hr}$ was selected as a basis for screening candidate alloys. It should be pointed out that, to establish an expected service life in pressurized-water reactors, substantially longer reference periods would be necessary. Specimens for corrosion studies at $300 \mathrm{C}$ in high-purity water were prepared in triplicate by shearing test coupons 1 by 0.75 by $0.70 \mathrm{in}$. from the wrought sheet. Approximately $0.003 \mathrm{in}$. was machined from each surface, and an additional $0.002 \mathrm{in.}$ was pickled from the surfaces in a $\mathrm{HNO}_{3}-5$ volume per cent $\mathrm{HF}-50$ volume per cent $\mathrm{H}_{2} \mathrm{O}$ solution. The specimens were exposed to static demineralized water at $300 \mathrm{C}$ for a total of $1000 \mathrm{hr}$, and removed from test, weighed, and examined at intermediate time intervals of $168,336,672$, and $1000 \mathrm{hr}$. Total weight gains in milligrams per square decimeter of surface were calculated for each period. Results for 1000 hr of exposure are summarized in Table 3.

The effect of niobium additions on the corrosion behavior of the zirconium alloys is illustrated in Figure 7. No consistent trends are evident from these results. In general, niobium appears to have little effect on the weight gains obtained after $1000 \mathrm{hr}$ of exposure to $300 \mathrm{C}$ water. This is consistent with reported observations that binary niobium additions have little influence on the corrosion behavior of zirconium. (3) There are indications from the data in Figure 7 that increasing niobium increases the amount of corrosion in $2 \mathrm{w} / 0$ molybdenum-0.1 w/o iron-0.05 w/o nickel- 3 to $4 \mathrm{w} / 0$ tin alloys. The reason for this effect is not yet apparent.

Figure 8 shows the effect of molybdenum additions on the weight gains of the zirconium alloys after $1000 \mathrm{hr}$ of exposure to $300 \mathrm{C}$ water. It is obvious from these curves that increasing the molybdenum content results in increased attack in the alloys. (This is in line with the known harmful effects of molybdenum additions to zirconium. (3)) The adverse effects of molybdenum are most evident at the higher niobium levels and indicate the possibility of a cumulative effect of the alloy additions.

The weight gains obtained after exposing binary zirconium-tin alloys $1000 \mathrm{hr}$ to $300 \mathrm{C}$ water are compared in Figure 9. There appears to be no effect of tin on corrosion behavior under these conditions. However, exposure at higher temperatures and for longex periods would be expected to reveal a drop in corrosion resistance with increasing tin content. An interesting, and as yet unexplained, beneficial effect of tin was observed when total alloy content was considered. This effect is shown in Figure 10. At the $4 \mathrm{w} / 0$ tin level, all specimens containing up to $5 \mathrm{w} / 0$ total alloy additions exhibited weight gains of less than $30 \mathrm{mg}$ per $\mathrm{dm}^{2}$ in $1000 \mathrm{hr}$ of exposure. A progressive increase in attack was noted at the lower tin levels of 3 and $2 \mathrm{w} / 0$. Although tin is known to counteract the adverse effects of nitrogen, and, to a lesser extent, those of aluminum, carbon, and titanium, at impurity levels, it is not considered as exerting significant beneficial effects in the case of molybdenum, niobium, and other elements at alloying levels. 

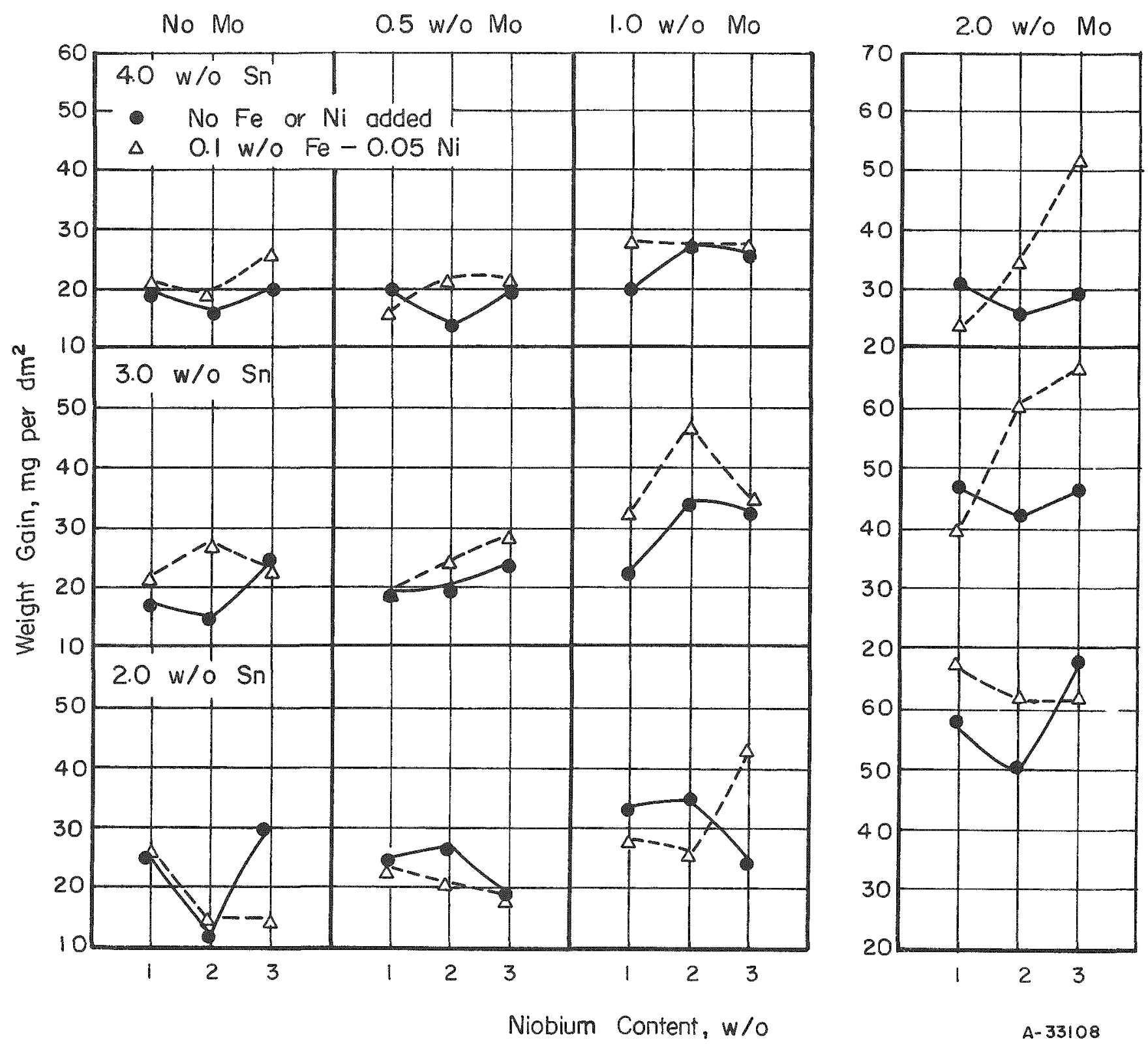

FIGURE 7. ¿FFECT OF NIOBIUM ADDITIONS ON THE CORROSION BEHAVIOR OF ZIRCONIUM-MOLYBDENUM ALLOYS

Specimens were exposed $1000 \mathrm{hr}$ to $300 \mathrm{C}$ water. 


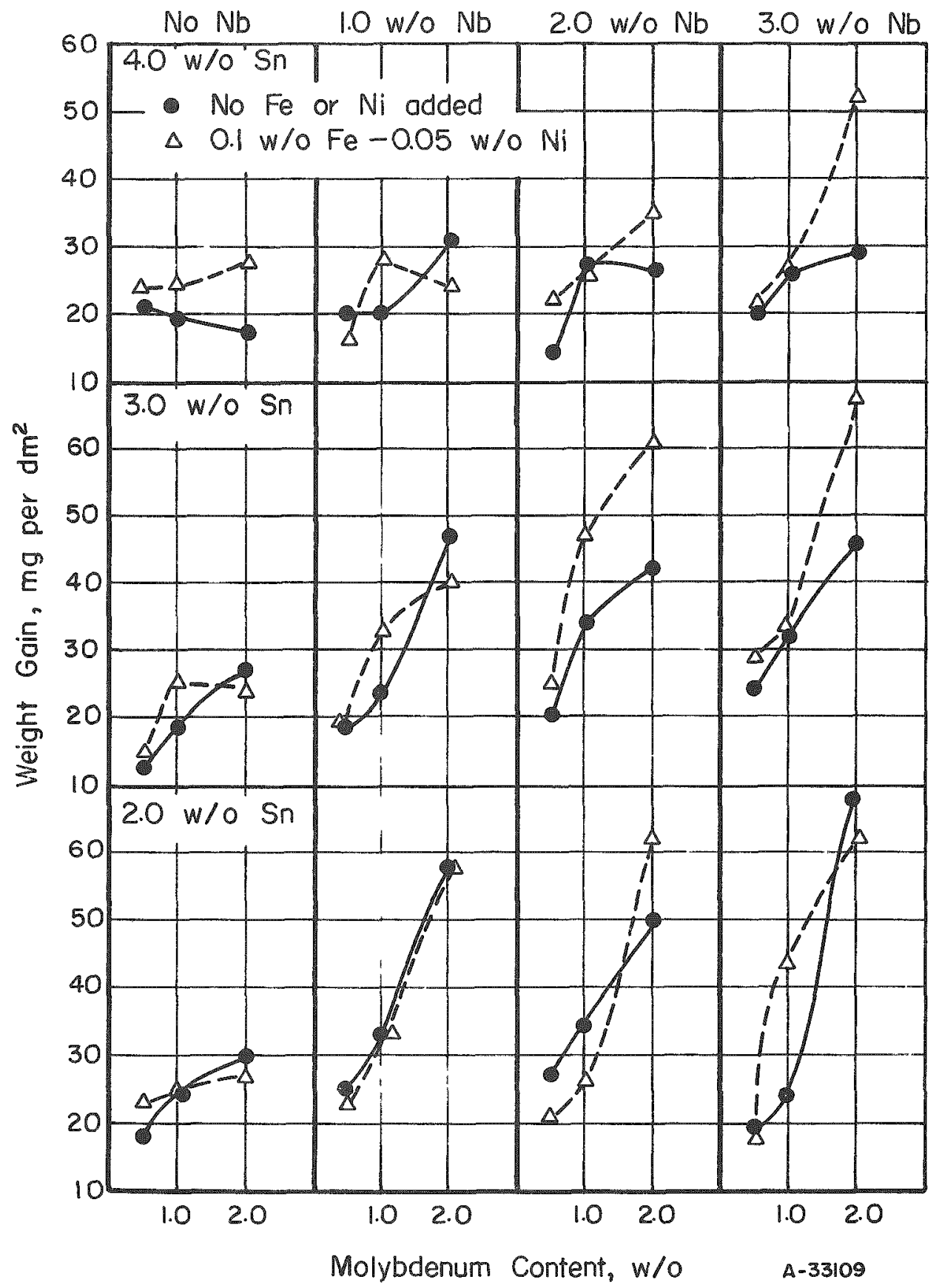

FIGURE 8. ¿EFECI OF MOLYBDENUM ADDITIONS ON 1 HE CORROSION BEHAVIOR OF ZIRCONIUM-NIOBIUM ALLOYS

Specimens were exposed $1000 \mathrm{hr}$ to $300 \mathrm{C}$ water. 


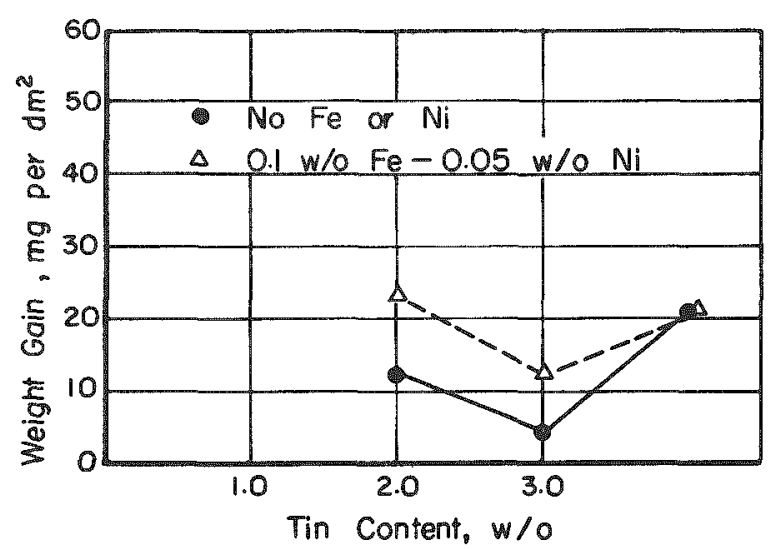

FIGURE 9. COMPARISON OF WEIGH' GAINS OF ZIRCONIUM-IIN ALLOYS EXPOSED $1000 \mathrm{HR}$ TO $300 \mathrm{C}$ WATER

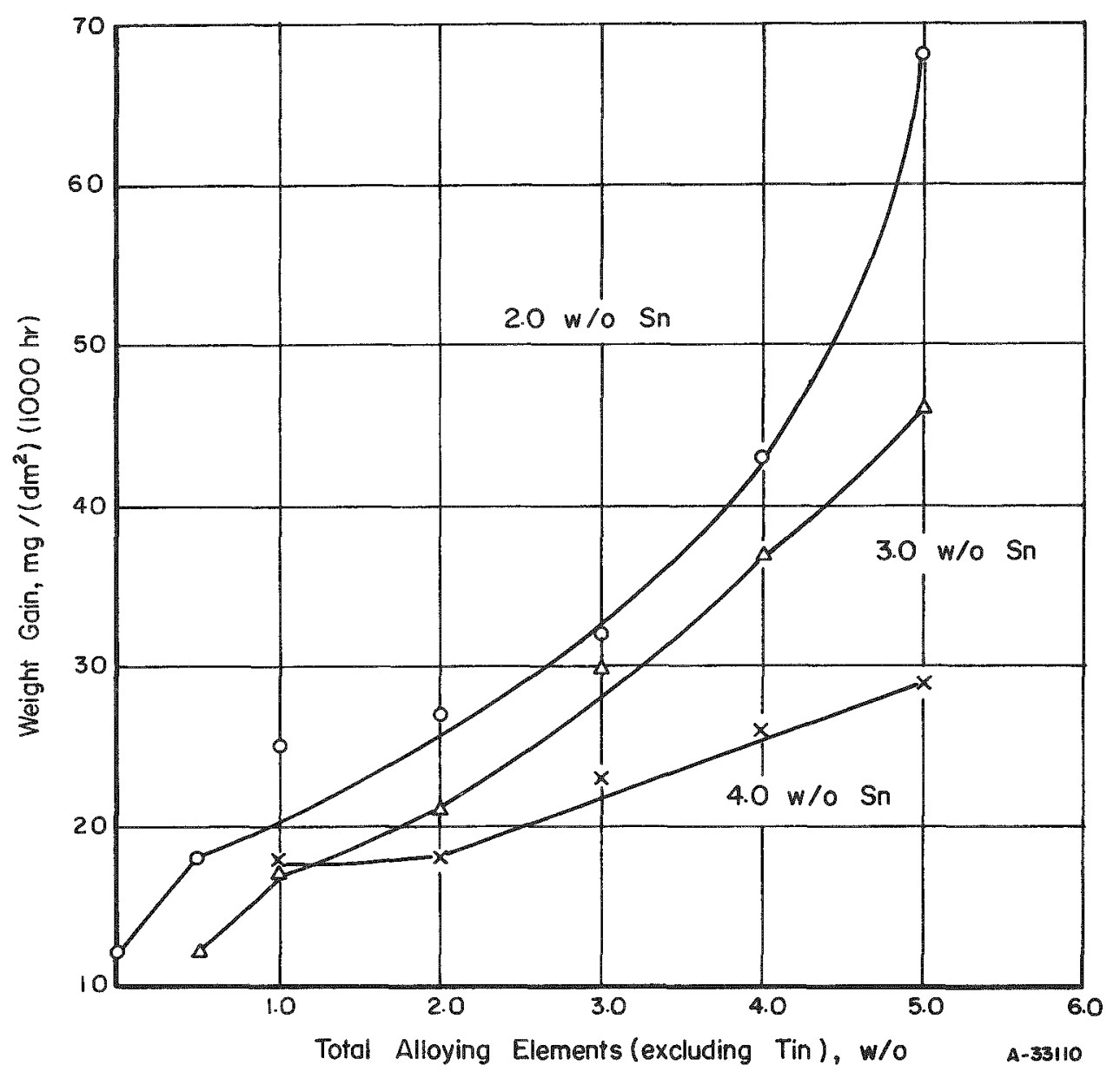

FIGURE 10. EFFECT OF TIN ON TOTAL WEIGHT GAIN OF ZIRCONIUM-BASE ALLOYS EXPOSED $1000 \mathrm{HR}$ TO $300 \mathrm{C}$ WATER 
TABLE 5. ALLOYS SUGGESTED FOR FURTHER EVALUATION

\begin{tabular}{|c|c|c|c|c|c|c|c|c|}
\hline \multicolumn{5}{|c|}{$\begin{array}{l}\text { Nominal Alloying Additions } \\
\text { (Balance Zirconium), w/o }\end{array}$} & \multicolumn{2}{|c|}{$\begin{array}{l}\text { DPH, } \mathrm{kg} \text { per } \mathrm{mm}^{2} \\
\text { Room }\end{array}$} & \multirow{2}{*}{$\begin{array}{l}\text { Weight Gain in } \\
300 \mathrm{C} \mathrm{Water} \\
\mathrm{mg} /\left(\mathrm{dm}^{2}\right)(1000 \mathrm{hr})\end{array}$} & \multirow{2}{*}{$\begin{array}{c}\text { Approximate Calculated } \\
\text { Thermal-Neutron } \\
\text { Cross Section, } \\
\text { barn per atom }\end{array}$} \\
\hline$\overline{S n}$ & Mo & $\mathrm{Nb}$ & $\mathrm{Fe}$ & $\mathrm{Ni}$ & Temperature & $300 \mathrm{C}$ & & \\
\hline 2.0 & 0.5 & -- & -- & -- & 290 & 140 & 18 & 0.198 \\
\hline 2.0 & -- & 2.0 & 0.1 & 0.05 & 307 & $140(a)$ & 14 & 0.200 \\
\hline 2.0 & -- & 3.0 & 0.1 & 0.05 & 297 & $150(a)$ & 14 & 0.213 \\
\hline 3.0 & - & -- & 0.1 & 0.05 & 312 & 160 & 12 & 0.189 \\
\hline 3.0 & 0.5 & -- & 0.1 & 0.05 & 304 & 165 & 15 & 0.199 \\
\hline 3.0 & 0.5 & 1.0 & 0.1 & 0.05 & 319 & $160(a)$ & 19 & 0.209 \\
\hline 4.0 & 0.5 & $-\infty$ & -- & -- & 333 & 165 & 21 & 0.205 \\
\hline \multicolumn{2}{|c|}{ Zircaloy-2(b) } & $\ldots$ & -- & - & 230 & 104 & 24 & 0.195 \\
\hline \multicolumn{2}{|c|}{ Zircaloy-2(c) } & -- & -- & -- & 210 & 104 & 13 & 0.195 \\
\hline
\end{tabular}

(a) Estimated hot-hardness values from similar alloys.

(b) Values obtained in this testing program.

(c) Values obtained from literature. 


\section{CONCLUSIONS}

Two general conclusions can be drawn from the results of the program:

(1) Alloys can be prepared which show increased hardnesses over Zircaloy-2 at both room and elevated temperatures while still retaining corrosion resistance in $300 \mathrm{C}$ water for $1000 \mathrm{hr}$ which is comparable to that of Zircaloy-2.

(2) The survey has shown that seven alloys have short-time corrosion properties in $300 \mathrm{C}$ water comparable to Zircaloy- 2 and strengths greater than Zircaloy -2 .

\section{RECOMMENDATIONS}

Completion of this phase of the program has indicated that several alloys can be selected which show promise as a prospective cladding material for use in water at $300 \mathrm{C}$. Alloys which show the optimum combination of hardness at room temperature and $300 \mathrm{C}$, corrosion life in $300 \mathrm{C}$ water, and thermal-neutron cross section (calculated $(4)$ ) are shown in Table 5.

Naturally, further evaluation of these alloys is necessary before they can be of use as cladding material. It will be necessary to determine their mechanical and creep properties and their thermal conductivity. Alloys which show the best combinations of these properties should undergo further evaluation in a well-planned irradiation program。

\section{ACKNOWLEDGMENT}

The authors wish to express gratitude to BMI staff members W. Berry and W. Boyd for their helpful discussions of the corrosion results.

\section{REFERENCES}

(1) Chubb, W. "Irigh-Strength Zirconium Alloy: Zr-4 Wt Pct Sn-1.6 Wt Pct Mo", Trans. AIME, 208, 461 (April, 1957).

(2) Schwope, A. D., and Chubb, W., "Mechanical Properties of Zirconium-Tin Alloys", BMI-798 (December 22, 1952).

(3) The Metallurgy of Zirconium, National Nuclear Energy Series, McGraw-Hill Book Company, New York (1955), "Corrosion of Zirconium and Its Alloys" (B. Lustman), p 663. 
(4) Schwope, A. D., Marsh, L. L., and Chubb, W., "Development of Zirconium Alloys, Part 1", BMI-79 (August 8, 1951).

JAD:FRS:RFD/min 